\title{
Trump and the Trumpists
}

\author{
Wolfgang Streeck
}

$\mathrm{S}$ TRANGE PERSONALITIES ARISE in the cracks of disintegrating institutions. They are often marked by extravagant dress, inflated rhetoric, and a show of sexual power. The first Trumper of the postwar era was the Danish tax rebel, Mogens Glistrup, the founder of the nationalist Progress Party, who, having put his principles into practice, went to prison for tax evasion. Geert Wilders in the Netherlands and Boris Johnson in England are hairstyle Trumpers. Pim Fortuyn and Jörg Haider were both dandies. They died in their finery. Beppe Grillo, Nigel Farage, and Jean-Marie Le Pen, are each one third of a full Trump.

Trumpers generate their populist charisma among Trumpists by defying convention; they appear extraordinary to those who are intimidated but not impressed by society's machinery of social control. ${ }^{1}$ With hindsight, it seems as though the capitalist democracies have been waiting for their Trumpers, men and women eager to liberate public speech from its commitment to the unbelievable. Donald Trump's promise to make America great again is an acknowledgement that the United States is a power in decline, embarrassingly unable since Vietnam to win, or even to finish, any of the wars that it started. When Trumpers ask about NATO, they are asking why NATO should continue to exist a quarter century after the end of the Soviet Union. Calls for economic protectionism raise the question, long taboo among liberal internationalists, of whether new free trade agreements are really to everyone's benefit, and why, in particular, the government of the United States should have let its country deindustrialize. The United States has an elaborate immigration policy, and yet there are eleven million illegal immigrants in its territory. ${ }^{2}$ Trumpers say this is odd, and Trumpists agree with them.

$\mathrm{I}$ N The Eighteenth Brumaire of Louis Bonaparte, Karl Marx recounted the coup d'état of 1851 by which the nephew of Napoleon I, Louis Bonaparte, seized power, ruling France first as its president, and a year later as its emperor. ${ }^{3}$ He governed as Napoleon III until 1871, when the Prussian army under Helmuth von Moltke put an end to his administration, along with his amour-propre.
Marx described Bonapartism as a popular form of government by personal rule. It arose, he argued, in stalemated European societies, with the capitalist class too divided, and the working class too disorganized, to instruct or inform the government. The result was a degree of relative state autonomy, one expressing, even as it masked, a deadlock between social classes. ${ }^{4}$

Bonapartist politics is driven by the idiosyncrasies of its Bonaparte. ${ }^{5}$ This is not a recipe for effective rule. Since a capitalist society under Bonapartism lacks the power to control, or contain, market forces, capitalists can afford to let their Bonaparte stage spectacles of political bravado; behind the scenes, markets do what markets do. In reflecting on the two Napoleons, Marx remarked that the first was a tragedy, but the second, a farce. ${ }^{6}$

No one wishes to see too many farces play on the international political stage. The slow breakdown of state-administered capitalism in the 1970s was followed by the catastrophic collapse of its neoliberal successor in 2008, an event, or series of events, that destroyed the credibility of neoliberalism as an economic doctrine ${ }^{7}$ and left the governors of global capitalism clueless. ${ }^{8}$ There are today profound disagreements about whether the proper location of government should be at the national or international level. There is also the worldwide demise of center-left politics; the fragmentation of national party systems, often making government formation difficult if not impossible; and the simultaneous increase of inequality and indebtedness across the developed capitalist economies. Trump won the United States presidential election with the support of a disorganized declining class, the industrial workers of middle America, who are comparable in their own way to Marx's smallholding peasants of mid-eighteenth century France. ${ }^{9}$ Hillary Clinton proved unable to forge a coalition between Wall Street and Main Street, or between the big and petite bourgeoisie, or between Silicon Valley and industrial workers, or between the forces of finance and Bernie Sanders. On the opposite side of a political system in decay, the Republican party proved unable to bridge the gap between old Republicanism and the tea party, or between social modernizers and religious fundamentalists, or between urban hedonists 
and rural puritans, or between international interventionists and national protectionists.

Fissures grew into cracks, and an accumulating system of cracks opened a path for an outsider like Trump to capture the Republican nomination. Had the Democratic establishment defended itself as weakly as the Republican establishment, ${ }^{10}$ Trump might have been defeated by Sanders.

$\mathrm{O}$ VER THE PAST quarter century, the center-left made a historic commitment to internationalism, a movement both promoting and requiring economic and social modernization. Now it is declining into desuetude. It is against this background that Trump and Trumpism must be understood. In the 1990s, the center-left placed its hopes for restoring growth and consolidating public finance on liberalized international markets. A worldwide effort at industrial and social restructuring followed. International competition put pressure on national economies to become more efficient. Economic losers were punished by ever-lower wages and reduced social security benefits. Economic winners were rewarded by higher profits and lower taxes. Policies to this effect were hard to sell to center-left voters, so they were attributed to the irresistible natural force of globalization. In this way, the center-left hoped to escape responsibility for the pain inflicted on its constituents. The bitter medicine did not work; nor was the center-left granted political immunity. In all countries of the developed capitalist world, the number of losers increased until political entrepreneurs sensed their opportunity and entered the public scene.

The rise of the Trumpists was made possible by the decline of the center-left in the United States, Italy, France, the UK, Austria, the Netherlands, and even Germany, where the losers in the former GDR (Deutsche Demokratische Republik), were among the earliest supporters of the new right-wing party, the AfD (Alternative für Deutschland). Those aggrieved by the accelerated internationalization of their societies felt abandoned by their national state. Elites in charge of public affairs were judged guilty of having handed national sovereignty to international organizations. These charges were largely true. Global neoliberalism has enfeebled the nation state, and with it, national democracy. Citizens most affected by these events had only their votes to express their displeasure. Trumpism took off, fueled as much in the United States as elsewhere by popular irritation at the vast public celebration of internationalization. Economic and cultural elites entered an international space rich in their rights, at ease both in and out of national states. If democracy is understood as the possibility of establishing social obligations toward those luckless in the marketplace, the global elites had entered into, or created, a world in which there was a great deal of lucklessness and not many obligations.
For those plotting to take advantage of growing discontent, nationalism appeared as an obvious formula both for social reconstruction and political success. The winners and the losers of globalism found themselves reflected in a conflict between cosmopolitanism and nationalism. The old left having withdrawn into stateless internationalism, the new right offered the nation-state to fill the ensuing political vacuum. Liberal disgust at Trumpian rhetoric served to justify the withdrawal of the left from its constituents, and to explain its failure to help them express their grievances in civilized public language. Discontent grew fast.

The Trump presidency is both the outcome and the end of the American version of neo-liberalism. Having commenced crumbling in the era of George W. Bush, the neo-liberal regime managed to regain an appearance of vitality under Barack Obama. With his departure, it was bound to collapse under the weight of its contradictions, and, indeed, absurdities. Clinton's daring attempt to present herself as advocate of those Americans "working hard and playing by the rules," while collecting a fortune in speaker's fees from Goldman Sachs, was destined to fail. So, too, was Clinton's insistence that it was the historical duty of American voters to elect her as their first female president. Transgendered restrooms infuriated everyone except those seeking access to them, no matter the Obama administration's attempt to depict bathroom access as a civil right. ${ }^{11}$ Deep down, no one cared.

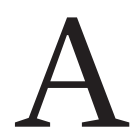
LMOST A CENTURY ago, Max Weber drew a distinction between class and status. ${ }^{12}$ Classes are constituted by the market; status groups by a particular way of life and a specific claim to social respect. Status groups are home-grown social communities; classes become classes only through organization. The Trumpist electoral machine mobilizes its supporters as a status group. It appeals to their shared sense of honor more than to their material interests. ${ }^{13}$ In this, Trumpism follows New Labour and New Democrat neo-liberalism, which deleted class from their political vocabulary. In its stead, they redefined the struggle for social equality as one over identity, that is, over the symbolic recognition and collective dignity of an indefinite number of ever narrower status groups. Neoliberalism had failed to anticipate that the discovery by experts and politicians of ever new minorities may make the demobilized working class feel abandoned in favor of special interests. Their discovery and celebration inevitably demoted the interests of the working class. As the United States was transformed into a polity of status groups, the working class lost its sense of identification with the country as a whole, if only because it is this class, reduced to one identity and interest among others, that is now blamed for a rich variety of social malignancies, from racism and sexism to gun violence and educational and industrial decline. ${ }^{14}$ 
Whereupon the takeoff of Trumpist propaganda. The center-left took satisfaction in informing Americans deprived of an accessible identity that they were shortly to become "a minority in their own land." They found their predicted irrelevance galling; its celebration, intolerable. Trumpism promised them a restauration of their honor. The country would be reconstituted as a united status group, one defending its integrity against both immigrants and urban elites. Exactly like the center-left politics of identity, Trumpism is all about collective honor. Unlike the center-left, it speaks to the silenced majority of a disorganized class. A class that is resentful about its relegation to the status of a moral minority, one less worthy of respect than other minorities due to past offenses against the new spirit of openness and diversity.

The electoral dynamics of Trump's victory in the United States are now well understood. The election was as much about Clinton losing as Trump winning. Unlike other Trumpists, Trump did not have to bring about an increase in voter turnout in order to win..$^{15}$ Having insulted Trump supporters as a "basket of deplorables," Clinton placed her bets on a collection of status groups defined by color, gender, national origin, sexual identification, and the like. She early on conceded Pennsylvania, Ohio, Michigan, and Wisconsin. Clinton also relied on her financial backing by Wall Street and Silicon Valley, as well as a hoped-for glamour infusion from her supporters in the entertainment business, such as Meryl Streep and Beyoncé. As a champion of those average Americans who worked hard and played by the rules, Clinton was embarrassed by her wealth and the suspicious ways in which she had earned it. ${ }^{16}$ Trump received the lion's share of his votes from the victims of deindustrialization in the center of the country. ${ }^{17}$

The result was an almost perfect division of the political landscape between Trump majorities in the center and Clinton majorities along the coasts. Clinton having focused on status rather than class, class was left to Trump, who in an act of instinctive political genius, made of class another, forgotten, dishonored status group. This enabled him to attract voters in still relatively comfortable economic circumstances who no longer felt sufficiently respected by the forces of cultural modernization. Trump's foulmouthed public persona and his outrageous appearance did not deter them, apparently because what he said was closer to their heart than conventional public speech. Nor were his voters deterred by the fact that he was no policy expert. Supporting him was an expression of their lost faith in the problem-solving capacity of conventional politics. ${ }^{18}$ While Trump's appeal was about respect, Clinton's rejection was about class. White working class women voted for Trump 62:34, ${ }^{19}$ and compared to Obama, Clinton lost among blacks and Latinos, as well as among Asians. $^{20}$
A MONG THE STRUCTURAL cracks in contemporary societies in which Trumpism flourishes is a rapidly growing cleavage between cities and their deindustrialized, more or less rural, hinterland. Cities are the growth pole of postindustrial societies. They are international, cosmopolitan, and politically pro-immigration, in part because their success in global competition depends on their ability to attract talent from all over the world. Cities also require a supply of low-skilled and low-paid service workers, who clean offices, provide for security, prepare meals in restaurants, deliver parcels, and take care of the children of dual career families. ${ }^{21}$ The white middle class can no longer afford ever-rising urban rents; they find themselves living in growing communities of immigrants, or they leave and move to the small-town provinces. ${ }^{22}$

Geographical separation has deeply divisive cultural and political consequences. Urban elites can easily imagine themselves moving from one global city to another; moving from New York to Ames, Iowa is another matter. National borders are less salient to urban elites than the informal borders between urban and rural communities. As urban labor markets turn global, job applicants from the national hinterlands must compete with talent from all over the world. Globalization creates an incentive for governments and employers not to invest too much in education. Why bother? They can always poach skilled labor from other countries. This is how the United States combines one of the worst school systems in the world with the world's best universities and research centers.

There is an almost insuperable cultural barrier between the city and the country, something long known to city and country dwellers alike. City dwellers develop a multicultural, cosmopolitan outlook. As their values converge on their interests, what used to be social liberalism edges into free-market liberalism. Seen from the perspective of the provinces, of course, elite cosmopolitanism serves the material interests of a new class of global winners. Mutual contempt is reinforced by self-imposed isolation, both sides speaking only to and within their camps, one through the media, located in the cities, the other through self-constructed private internet channels.

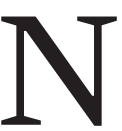

EOLIBERAL MODERNIZATION comes with a cultural reeducation program. The liberal war against tradition, undertaken by metropolitan elites, and neoliberal economic reforms are related. The first serves as a cover for second. It crowds political economy from public attention. But both are about a redefinition of social solidarity and economic egalitarianism. Social communities based on a shared sense of obligation are always at risk of harboring or relapsing into an attitude inimical to capitalist progress. Neoliberalism champions individual achievement over collective solidarity. In terms of T. H. 
Marshall's seminal analysis of the European welfare state, this amounts to a reversal of the move from social rights of collective protection based on citizenship in a (national) political community, to civil rights of equal participation in (supranational) markets. ${ }^{23}$

Nations are imagined communities. ${ }^{24}$ Nation building entailed the creation of formal institutions extending previously informal, communal bonds of solidarity to all co-nationals. Globalization favors the equal access of everyone to worldwide markets. It has no use for national citizenship or national citizens. Another moral system is at work. ${ }^{25}$ Cultural reeducation is required to erase traditional solidarity and replace it with a morality of equal access and equal opportunity regardless of status (such as "race, creed, and national origin"). Justice is served as soon as market access is equalized. The replacement of class solidarity by status rights demands flexible adjustment to changing market conditions. The morality of marketization entails a categoric delegitimization of distinctions. Empathy and benevolence become moral duties with respect to everyone, rather than one's neighbor. Social rights are displaced by civil rights, a process which, as Hannah Arendt saw clearly in 1948, inevitably dilutes to near-invisibility any system of effective social protection.

For the domestic politics of a nation-state undergoing neoliberal redefinition, this has profound consequences. Classes struggling over the correction of markets give way to status groups struggling over access to them. At issue are not the terms of exchange and cooperation between conflicting class interests, or the limits of exploitation of one class by another, but status groups with established market access excluding status groups without it from competition. Political morality lies in opening up competition by removing barriers to entry, not in containing it through institutionalized limits to commodification. For groups that already have market access, this means a moral duty, in the name of equality, to allow themselves to be challenged by newcomers, whoever they may be-fellow citizens, immigrants, or residents of other countries-at the risk of being outcompeted and having their lives disrupted as a result.

The shift from class to status has left the remnants of the traditional working class deeply resentful. ${ }^{26}$ Trumpism is the belated political eruption of this resentment. In the United States, the UK, France, Sweden, and Germany, the old working class, gathered in declining regions and cut off from glimmering global cities, has for some time felt sidelined by what it perceives as a new politics of entitlement by victimhood. ${ }^{27}$ Their moral and economic isolation was exacerbated by the media and their reeducation campaigns. Arlie Russell Hochschild has described the deep divisions between traditional American communities and a hegemonic urban culture declaring it a moral duty for citizens to extend communitarian feelings of compassion, solidarity, and brotherhood from neighbors and friends to everybody, from kind to mankind and indeed humankind. ${ }^{28}$ Those unable to comply with the demand for conspicuous compassion are widely regarded as morally defective. Better to stay silent. ${ }^{29}$ Resistance is punished by cultural marginalization, which in an especially delicate exercise in social irony, is itself becoming a form of victimization.

To the extent that Trumpism is a cultural movement, it represents a backlash against the degradation of a disorganized class; and it celebrates, and often sanctions, a smoldering desire for symbolic rehabilitation. Trump's ascendency, in particular, coincides with a dramatic national loss of status in the larger international arena. The American working class has strongly supported the wars undertaken by the United States, and it can see that by never winning them, the United States has always lost them. The American heartland has always been emotionally invested in global power. ${ }^{30}$ Successive defeats in war left deep wounds in its collective consciousness, as did the indifferent respect paid to veterans returning from the battlefields. That the country with the world's most powerful military had so often been unable to prevail over its enemies, the heartland attributed to faint-hearted and feckless leadership. Hurt pride resulted in simultaneous calls for a complete withdrawal from foreign adventures, and for an unrestrained use of military force. Trumps seem to emerge easily in countries with a colonial past-the United States, France, the UK, the Netherlands, and also Russia. Collective memories of being at the center of the world, or at least of a world of one's own, seem to make it more difficult to accept relegation to the status of one country among others.

$O$ wie ist alles fern und lange vergangen is a sentiment that an entire people can share.

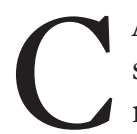
An trump Govern? Could Le Pen? Or Grillo? In a system of personal rule, personal defects matter: narcissism, fickleness, a short attention span. It remains to be seen if Trump has the time, and, indeed, the will, to study dossiers or even to listen to advice. ${ }^{31}$ Trump's performance during his first weeks in office has been erratic, messy, and incompetent. Early in his presidency, it seemed conceivable that he might resign during his first term, perhaps undermined by the intelligence community he had insulted during the campaign. He could also be forced to resign over conflicts of interest, or be declared unfit to serve, under the 25th Amendment. ${ }^{32}$ His cabinet appointments, on the other hand, indicate an attempted reconciliation with both the military and the national security establishment, buying stabilization in office with concessions on policy, especially on NATO, Russia, and global affairs generally.

An elected president can stray far from his campaign rhetoric without popular punishment. In this, Trump 
might learn from his predecessor. But even if Trump learns how to govern, there is no reason to believe that he will be better than his predecessors at dealing with the crises of global capitalism and the international state system that have brought him to power. Increasing inequality, rising debt, and low growth are not easily cured. Trumpism is, after all, an expression of the crisis, not its solution. If Trumpists feel bound by their electoral promises, they must put an end to neoliberal reform. This will not end the impasse between capitalism and society. In the absence of a stable class compromise between capital and labor, policy is doomed to become capricious. Perhaps Trumpism will make its departure from neoliberalism and free trade palatable to capital by increasing credit, debt, and inflation-another policy intended to buy time and little else. Nobody knows what Trumpists will do to shore up their political support if economic nationalism fails to produce the promised results.

Wolfgang Streeck is Director Emeritus and Professor at the Max Planck Institute for the Study of Societies in Cologne.

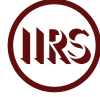

1. This essay is not on populism in general but only on a subtype of it, which I call Trumpism. Populism has a long and often dignified history, reaching back to the progressive era in the United States with the Minnesota Farmer-Labor Party and "Fighting Bob" La Follette's Progressive Party-and in any case there is left as well as right populism (Ernesto Laclau, On Populist Reason (London: Verso, 2005); Chantal Mouffe, On the Political (Abingdon: Routledge, 2005)). Today populism has become a dirty word, used by the established parties of postwar capitalist democracy to discredit their new challengers, from both sides of the political spectrum.

2. Similarly, European Trumpists insist, increasingly with success, on the questions of what exactly the "ever closer union of the people of Europe" as envisaged by the European Union treaties is to mean, and what the status of associated nation-states within that union is supposed to be-an issue that is strictly avoided in official Europe.

3. Karl Marx, The Eighteenth Brumaire of Louis Bonaparte (New York: Mondial, 2005). The Eighteenth Brumaire is also available online.

4. Within orthodox Marxism, the concept of Bonapartism represents its most significant departure from its fundamental base-superstructure paradigm.

5. As Marx writes on Bonaparte: "Just because he was nothing, he could signify anything." Quoted in Francis Wheen, Karl Marx: A Life (London: W. W. Norton \& Co., 2001), 157.

6. "Hegel remarks somewhere that all great world-historic facts and personages appear, so to speak, twice. He forgot to add: the first time as tragedy, the second time as farce.” Karl Marx, The Eighteenth Brumaire of Louis Bonaparte, chap. I.

7. Jonathan Ostry, Prakash Loungani, and Davide Furceri, “Neoliberalism: Oversold?" Finance \&t Development 53, no. 2 (2016): 38-41.

8. See Wolfgang Streeck, Buying Time: The Delayed Crisis of Democratic Capitalism (London: Verso Books, 2014); Mervyn King, The End of Alchemy: Money, Banking; and the Future of the Global Economy (London: W. W. Norton \& Company, 2016).

9. The concept of social disorganization is illustrated in Chapter 7 of The Eighteenth Brumaire where Marx explains why the French peasants, Louis Napoleon's main source of support, were unable to rule as a class although they were the vast majority of the French citizenry:

Each individual peasant family is almost self-sufficient, directly produces most of its consumer needs, and thus acquires its means of life more through an exchange with nature than in intercourse with society... Thus the great mass of the French nation is formed by the simple addition of homologous magnitudes, much as potatoes in a sack form a sack of potatoes.

Karl Marx, The Eighteenth Brumaire of Louis Bonaparte, chap. VII.

10. Which, given the disorder in its own camp, might have been happy with Clinton winning the Presidency and then doing the bidding of the Republican core constituency, financial capitalism.

11. For a fascinating eyewitness account of how Obama experienced and reacted to the defeat of the center-left neoliberal project is provided see David Remnick, "It Happened Here: A President Confronts an Election that Changes Everything-and Imperils his Legacy," The New Yorker, November 28, 2016, 54-65.

12. Max Weber, Economy and Society: An Outline of Interpretive Sociology, ed. Günther Roth and Claus Wittich, 2 vols. (Berkeley: University of California Press, 1978).

13. This is why Trumpist leaders can be and often are of great wealth even though their followers may be poor; see Louis Bonaparte and his peasant supporters. On the one hand, while Trump-like leaders can be rich, they are typically considered upstarts by families of old money.

14. Trumpist politics of honor and respect plays out differently in different national environments. One reason why East Germans, generously endowed with subsidies by the federal government, so often vote for Die Linke or for AfD seems to be that they find what they call their biographies not adequately appreciated in the united country.

15. In 2012, 90 million voters out of 220 million stayed home (41\%), in 2016 it was 93 million out of 230 million (40\%).

16. The Clinton family wealth is reported to have increased from minus eight million dollars in 2000 to about 110 million dollars in 2016 (Tom Gerencer, "Hillary Clinton Net Worth," 
Money Nation, November 1, 2016.). Disentangling the family assets from those of the Clinton Foundation seems difficultwhich undoubtedly contributed to widespread suspicions of corruption as raised by the private email server used by Clinton as Secretary of State, and Clinton's Goldman Sachs fees for speeches (US\$675,000 for three appearances) the contents of which she refused to disclose. That Trump is a lot richer than Clinton didn't apparently matter to his voters because he made his fortune, to the extent that he didn't inherit it, as a businessman rather than as a politician-the former being considered legitimate, the latter not.

17. On the devastations visited on the American working class by de-industrialization, see most recently Anne Case and Angus Deaton, "Mortality and morbidity in the 21st Century," Brookings Papers on Economic Activity, March 17, 2017.

18. As David Paul Kuhn, drawing on survey data, wrote in The New York Times on December 26, 2016:

Bluntly put, much of the white working class decided that Mr. Trump could be a jerk. Absent any other champion, they supported the jerk they thought was more on their side-that is, on the issues that most concerned them.

David Paul Kuhn, “Sorry, Liberals. Bigotry Didn’t Elect Donald Trump," The New York Times, December 26, 2016.

19. Indicating that the attempt to forge a politically united status group out of women from different classes had failed. Black (and immigrant) women may have noticed that their low wages as care workers were instrumental for white women's progress in their careers.

20. Relative to this, the impact of the so-called fake news can only have been miniscule. The fake news theory of Trumpism assumes that lies are today more important in politics than in the past; that real facts are easily distinguished from fake facts; and that more civilized political leaders, such as Bill Clinton, George W. Bush and Barack Obama, have done without lies. There are reasons to believe that truth as a political currency has been debased by the political mainstream to such an extent that lies by outsiders like Mr. Trump are no longer a problem to most voters. In any case, if there was anything fake in the 2016 campaign, it clearly included Clinton's self-presentation as a representative member of the hard-working American working class, as opposed to a self-enriching political class.

21. For a participant observer's description of the lives of legal and illegal immigrants in one of the biggest global cities of today, see Ben Judah, This is London: Life and Death in the World City (London: Picador, 2016).

22. Where they remain spatially and socially segregated, just as immigrant groups in their new country. For France, this-and its effect on political and voting behavior-is impressively described in Christophe Guilluy, Le Crépuscule de la France d'en haut (Paris: Flammarion, 2016).
23. T. H. Marshall, "Citizenship and Social Class," in Class, Citizenship and Social Development: Essays by T. H. Marshall (Garden City, NY: Doubleday, 1964), 71-134.

24. Benedict Anderson, Imagined Communities: Reflections on the Origin and Spread of Nationalism (London: Verso, 2006).

25. In effect this overlaps with contemporary urban cosmopolitanism in that it rejects nationalism and indeed any other communitarianism not just as outdated but as morally reprehensible.

26. For the US see Katherine Cramer, The Politics of Resentment: Rural Consciousness in Wisconsin and the Rise of Scott Walker (Chicago: University of Chicago Press, 2016). Cramer's book depicts in masterful detail the rural consciousness of small-town residents in Wisconsin who in 2016 became Trump supporters. The concept of resentment goes back to Friedrich Nietzsche, for whom it refers to wrathful fantasies of revenge and restored justice among utterly defeated and forever powerless losers.

27. The contrast between identity politics and class struggle in the widest sense, be it through trade unions or at the ballot box, is that in class struggle solidarity is mobilized in the service of your own interests whereas in identity politics it means sacrificing for the interests of groups of others. Identity-political altruism may therefore come more easily to the economically better placed. To those not belonging to their group, it may appear like egoistic interests camouflaged as charity-for example if the urban middle classes, economically dependent on a rich supply of cheap service labor, favor open borders for immigration.

28. Arlie Russell Hochschild, Strangers in Their Own Land: Anger and Mourning on the American Right (New York: The New Press, 2016).

29. In the German case, recipients of social security benefits of whatever kind are prone to compare their entitlements to those of refugees and asylum seekers, which are often much higher, making them feel abandoned by their government in favor of strangers.

30. It appears that here were the roots of the militia movement of the 1990s, stirred up unintentionally by George H. W. Bush's talk about a new world order after the demise of communism. Rumors spread that United Nations troops were about to disarm the "well-ordered militia" of American citizens. The movement culminated in a bomb attack on the Federal Building in Oklahoma City in 1995 that killed 161 people. It is conceivable that American Trumpism draws in part on similar sentiments as the militia movement of the 1990s.

31. But then, did Obama? Remember that during his presidency he found the time to play no less than 38 rounds of golf every year. Sam Weinman, "We've Crunched the Numbers, and It's Official: President Obama Played a Lot of Golf While in Office," Golf Digest, January 19, 2017.

32. According to Section 4 :

Whenever the Vice President and a majority of either the principal officers of the executive departments or of such 
other body as Congress may by law provide, transmit to the President pro tempore of the Senate and the Speaker of the House of Representatives their written declaration that the President is unable to discharge the powers and duties of his office, the Vice President shall immediately assume the powers and duties of the office as Acting President. 